\title{
The Extralinguistic Reality of the Armenian Question or Why Armenians Should Be Killed off (with special reference to E.T. Lawrence's standpoint)
}

\author{
Naira Gasparyan \\ Yerevan State University
}

\begin{abstract}
E.T. Lawrence, or Lawrence of Arabia, found "a perfect solution" to the Armenian question: the perfect race of Armenians" need a perfect massacre". In Lawrence's interview given to Lincoln Steffens (1919), entitled Armenians Are Impossible his intent suddenly becomes explicit at the end of their talk: Armenians are the last word in human impossibility, hence, they should be killed off.

To show what makes Lawrence arrive at such an inhuman idea of annihilating a whole nation, we intend to present the discussion with the help of a certain methodology. Methods of linguo-cultural analysis and purposive sampling, techniques of comparison and contrast, interpretation and representation have been applied to the material of our choice.
\end{abstract}

Key words: Armenians, Turks, linguo-cultural analysis, extralinguistic reality, Armenian question.

\section{Introduction}

In 1915 New York Times wrote that some aspects of the Armenian situation were presented in an article in Nuova Antologia (Rome), by a member of the Italian Chamber of Deputies, Signor Filippo Media. At the outset he noted that but for Disraeli's opposition, the Armenian question might have been settled at the Congress of Berlin, in 1878, by constituting an Armenian dependency under the nominal suzerainty of Turkey... Disraeli and his assistant Salisbury opposed it inflexibly. They feared that the new Armenian state would follow the example of the Balkan states and gravitate toward Russia, and would thus render Turkey more vulnerable in case of a Russian attack in Asia Minor (The Armenian Genocide - News Accounts from the American Press: 1915-1922). 
During his activity of a liaison officer T.E. Lawrence, famous as Lawrence of Arabia, while fighting against the Turks together with Arab tribes, managed to closely study the Armenians, their lifestyle, preferences, national characteristics, national wisdom, national demeanor. He also managed to notice that Christianity was not the main reason for the ruling Young Turkish government to declare Armenians state prisoners, otherwise said - enemies of Turkey. Arabs, both Muslim and Christian, were declared enemies and killed on the same scaffolds together with Armenias (Lawrence 1922).

Edgar T.A. Wigram (1922:19) interprets the hatred of the Turks for the Armenians emphasizing the fact that

Armenians were the only one of their subject nations of whom the Turks were afraid. The Arabs and Kurds were their coreligionists, and had no national cohesion. The Nestorian and Jacobite Syrians were either too few to be dangerous, or too thoroughly tamed by long subjection to have any desire to rebel. But the Armenians were numerous and imbued with national aspirations; and though the majority of them were inoffensive cultivators, they included a considerable number of intelligent and capable men. A small percentage too were active political propagandists, who continued to work persistently to overthrow the present regime. Under equal political conditions the Armenians would soon secure dominance: and that would be a subversal which the Turks could never endure. So when the Armenians grew restive the Turks resolved to "take precautions". They could not cope with them in cleverness, but in physical force they could.

The British noblemen Noel Buxton and Harold Buxton who travelled in Western and Eastern Armenia in 1913-1914 presented their accounts to the British Parliament. They wrote:

Europe should give up the hope that the Turks would ever be able to initiate reforms from within, moreover, Armenians should be perished from the Turks, or given arms to defend themselves.

(Buxton, Buxton 1914) 


\section{Armenian Identity and E.T. Lawrence's Interpretation} of the Armenians

In his Seven Pillars of Wisdom (1922) Lawrence mentions that those irritating subject races, thus were they perceived by the ruling stamp, that is by the Turks, had only one fault: they were not Turkish... Everything was going to be made Turkish and only for the Turks. Yeni Turan was supposed to house only Turks. The rest were to be massacred. So, the Turks began to cut the throats of their prisoners with knives, as though they were butchering sheep. (Lawrence 1922).

But, despite this horrible patches in one's destiny, Armenians survived and never surrendered. In the famous interview given to Lincoln Steffens, 1919, Lawrence, with some hidden envy, admits that Armenians have no lack of thrift, they know how to make money, handle their profit and become prosperous. Nevertheless, he considers that the British and Americans should teach them to work hard to succeed because Armenians prefer to make use of their brains rather than their hands. The fact that Armenians practise medicine, law, arouses his detest. But why shouldn't Armenians, practise medicine, law? This capability of Armenians, as it appears, was a source for concern and dissatisfaction for Lawrence. The trouble, as he thinks, is that all those old races that have been civilized, and once dominated the world and worked it, afterwards lost control. They have gone forward logically, psychologically, physiologically. Here the stem logically is repeated for three times for some stylistic effect. Lawrence thinks that Armenians do not care for hard labor, Armenians should work for Armenia and not Armenia for Armenians. Lawrence is sure that ex-civilized nations like Armenians are not lazy, anyhow they are too intelligent to work for others. The idea that Armenians are exploiters themselves may lead to some misunderstanding, since Armenians have always migrated because they themselves have been exploited. In foreign countries it took Armenians just a certain period to revive. Persians have always appreciated Armenians' loyalty and wit, creative talents and ability to participate, to invest in the well-being and prosperity of the State. Lawrence is sure that Armenians, are the most intelligent, the most perfectly selected, the most highly developed race in the world - from the civilized point of view. Here the superlatives are used to highlight certain national features that deeply displease Lawrence. A more perfect evaluation of a nation cannot be found. 
As the national history shows Armenians have succeeded in all the spheres. In 1653, a planter named Edward Diggs, considered to be the first Armenian in America, established a silk factory in America $(<\mathrm{z} 4$.invisionfree.com/Armenian _History/ar/t110.htm $>$ ).

There is also the fact ( $<\mathrm{z} 4$.invisionfree.com/Armenian_History/ar/t110.htm $>$ ) that the first information concerning patenting of innovations by Armenians is believed to relate to XVI century when in Venice the inventor Anton Surian received privileges and character of immunity on August 17, 1564 for the construction and method of "pontoon" salvaging of sank vessels from Adriatic Sea lagoon. The first claim for patent in the USA was given by another Armenian, chemist Christopher Der-Seropian, in 1854. It was immediately security-restricted by State Department of the country, because it concerned the method of production and green colour putting on dollar notes, which excluded the falsification possibility. It is security-restricted until the present time.

Nicolas Knaian's grandmother's story is another vivid example. We learn that on his father's side, the story goes that his grandfather provided chalk for the town they lived in. When he was taken away and killed with all the other Armenian men in the village, friendly Turkish neighbors protected his wife along with her two-year-old daughter, Armenouhi, saying that they couldn't kill her because she was the only one left who knew the process for making the chalk. (<http://www.northeastern.edu/nuwriting/the-truth-about-the-armeniangenocide $>$ )

Savage and inhuman invaders, as well as governmental restrictions, have always made Christian Armenians either continue their creative activity out of their native country, or strive for changing the social-political situation in their own country.

Very often, migration proved to be beneficial for their scientific activity like it was the case of Grigor Barseghyan who became Marie Curie fellow in London. Armenians have always lived in unbelievably complicated circumstances but they never gave up the hope, they worked hard and succeeded (Buxton, Buxton 1914). Quite another point is that Armenians have been weak at negotiating. This feature has not been well-developed most probably because of the specific Armenian straightforwardness, courage and wit, the ability to handle their national problems without others' help. The independent Armenian peaceful Republic of Artsakh is a vivid example of this. 
According to Lawrence,

the Jews themselves feel about Armenians the way the antiSemitic Europeans feel about the Jews; and so do the Greeks, Turks - all the other races that have ever had them on them. They feel that the Armenians would put them all to work. And they would. The Armenians are all that the Jews are, plus all that all the other races are —and they are Christians besides!

(Steffens 1919)

Armenians have never had the tradition of enslaving others, interfering with others' domestic affairs, but they do have the feeling of being historically just and, hence, Armenians easily detect any injustices imposed on them.

Irrespective of his specific hatred towards Armenians, Lawrence displays unbelievably compassionate attitude towards them, something that surprisingly hides his real intent.

From Lawrence's interview to Steffens it becomes obvious that

....he, Lawrence, had some inexpressible sympathy or - let me rather say - some knowledge or experience of the Armenians that gave him a human understanding for the Turks (and all the other near neighbors of the Armenians), who are forever trying to kill off this orphan race.

(Steffens 1919)

Lawrence seems to know a lot about Turkish-Armenian relations. To show that history repeats itself, that the Turkish attitude towards Armenians never altered, we would like to cite a passage (Hoffman 2011: 36-37), where Tessa Hoffman discusses a similar scene described by the Armenian historiographer Aristakes Lastiverttsi (1001-1080), who was the first Armenian author to give a detailed account of the Seljuk incursions into Armenia. He wrote about the seizure of Ani by the Seljuks already in 1064:

Babies were torn from their mothers' arms and hurled against stones, mothers shed tears and blood on their children. One and 
the same sword slew father and son alike. Old men and youths, priests and deacons were struck down by the same weapon..."

(Lastiverttsi $11^{\text {th }}$ cent., translated in 1985)

Lawrence uses an epithet orphan race to define the Armenians. Most probably he meant that pro-Turkish Superpowers did not want to take care of them, because they themselves were somehow indifferent towards the needs of Armenians. Steffens Lincoln, the reporter of the famous interview (Armenians Are Impossible, 1919), adds:

So he did not say that the Armenians should be killed off. He only gave me the impression, at the time, that that was the sole solution of the Armenian problem; and that that was his reason for desiring us Americans to take on the job.

(Steffens 1919)

The attributive word-combinations orphan race and sole solution in the above examples, seem to carry a certain message, but the message, which at first sight seemed implied, reveals Lawrence's hidden intent. It sounds like a resolution, a deadlock, a destiny for a whole nation, a nation which was said to be harmless.

Killing and wiping this orphan race off the world seems to be the only solution. But the worst is yet to come. All the other old rival races never finished the job, because their aesthetic pleasure in the killing of Armenians was fully satisfied before all the Armenians were dead. He seems to pronounce the sentence with indifference, but actually it turns out to highlight his dissatisfaction, although his intent is still implicit. Steffens writes:

He, Lawrence, made me feel, that the Turks shouldn't do it; they were too rough and ready - and not Christians. Nor the Greeks; they enjoyed it too much and were inefficient; they never finish anything, and when their aesthetic pleasure in the killing of Armenians was sated they quit. And so with all the other old rival races. They stopped work before all the Armenians were dead.

(Steffens 1919) 
Yet another very interesting feature of the Armenians is established by Lawrence - they are blessed by God, they cannot be abolished, cannot be wiped off the surface of the Earth. He is infuriated that they produce offsprings in a controlled and organized way. It is expressed through the stylistic repetition of to breed in the Past Indefinite Tense - bred and bred and bred, then Participle I of to spread - spreading and spreading which means they spread incessantly. There are millions of them, all meek, gentle, obedient, unprotesting, and lovable, attractive in a graceful way. In the last part of the sentence the consonants $s, p$, $b$, through alliteration, create an atmosphere of secrecy beneficial for breeding and spreading. The adverb slyly points out that The Armenians are selfcontained in private matters, they are clever and tend to keep thoughts and feelings private.

Even when they all went at the task together they invariably left a couple here and a couple there: Adams and Eves who, the moment one's back was turned, bred and bred and bred so that the next time one visited Armenia there were the Armenians as before, millions of them, all meek and lovely, but busy by day at business and at night secretly breeding and slyly spreading and spreading....

(Steffens 1919)

Millions of Armenians! Only imagine - millions of them after The Armenian Genocide of 1915. His dissatisfaction concerning the results of The Genocide seemed to have increased. His hatred was so unlimited that he expresses it implicitly through a simple exaggeration so that the next time one visited Armenia there were the Armenians as before, millions of them... Unfortunately, millions of Armenians have never lived in Armenia during the past couple of centuries, and he must have been very well-aware of that. Anyhow, his words make one think that after the Genocide of about one and a half million of Armenians the population of Armenia should have increased with geometrical progression.

From the next paragraphs we learn that since the English are practical, they think about solid things - oil, ore, air, the sea and they, the British, are not fit for a perfect massacre of the Armenians, they still have a dream, a task $-a$ world government must be founded. 
The shocking part of Lawrence's attitude towards the Armenians is that this almost perfect nation needs a perfect massacre. This 'adj + noun' syntagm is actually the carrier of the author's intent - this is the case when a nation should be abolished, massacred because of their positive features, because these positive features turn out to be very "dangerous" for the whole mankind. He suggests that the job be done by Americans who managed to have shown a similar attitude, a certain policy towards the Indians and nobody made a scandal... Besides, Americans never ceased to think that they had been right!

\section{Conclusion}

The problem with the Armenians remains obscure and controversial - they are creative, harmless, thrifty, graceful, intelligent, gone forward... and just for these reasons they should be killed off. Then, all of a sudden, with the methods and technique applied to the material, we discover the unique and astounding reason why Armenians should be killed off... It is because they, Armenians, will never obey foreign forces who intend to exploit them in their own Armenian mines! It is because Armenians love intellectual work, personal and national freedom, so, they will never become slaves; it is because they know how to survive and be successful - not only on their own soil in Armenia, but also in any foreign country.

Lawrence was a successful liaison officer and a British spy who happened to make Mustafa Kemal Pasha, Ataturk, work on the British as a spy. Although Lawrence was a keen expert in world cultures, he was mistaken to think that Armenians will make the whole world work for them. Anyhow, he perfectly understands that Armenians will never be abolished because they manage not to be killed off. Besides, Armenians know how to breed and spread.

\section{References:}

1. Armenian Immigration. Available at: <www2.needham.k12.ma.us/nhs/cur/ kane98/kane_p6_immig/armenian/Luder.html> [Accessed March 2016].

2. History of Armenia, p. 35. Available at: $<$ www.historyofarmenia.am/images /menus/728/HJP.pdf $>$ [Accessed June 2016].

3. Hoffman, T. (2011) One Nation - Three Sub-Ethnic Groups. The Case of Armenia and Her Diaspora. Yerevan: Narek. 
4. Issue Three / NU Writing. Available at: <www.northeastern.edu/nuwriting/ the-truth-about-the-armenian-genocide $>$ [Accessed June 2016].

5. List of Armenian Scientists and Philosophers. Available at: <www.en.wiki pediaorg/wiki/List_of_Armenian_scientists_and_philosophers $>$ [Accessed January 2016].

6. RIA: Inventions of Armenians. Available at: $<$ http://ria.am/en/about-armenia/ inventions-of-armenians.html $>$ [Accessed January 2016].

\section{Sources of Data:}

1. Armenians are Impossible. / Interview with Lawrence of Arabia in 1919 by Lincoln Steffens. Available at: <http://armenians-1915.blogspot.com/2008 /05/2471-armenians-are-impossible-interview.html> [Accessed April 2015].

2. Buxton, N.; Buxton, H. (1914) Travel and Politics in Armenia. London: Smith, Elder \& Co.

3. Lastiverttsi, A. (1985) History Regarding the Sufferings Occasioned by Foreign Peoples Living around Us. / Tr. and ed. by R. Bedrosian. N.Y.: NY Publishers.

4. Lawrence, E.T. (1922) Seven Pillars of Wisdom. UK: Private Edition.

5. Wigram, E.T. (1922) The Cradle of Mankind. Life in Eastern Kurdistan. London: Adam and Charles Black.

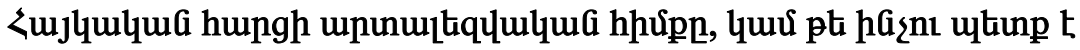

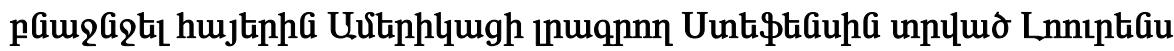 Unupugnt hunguqnnısgh huuunulua Gjnıph hhưuG ไnu}

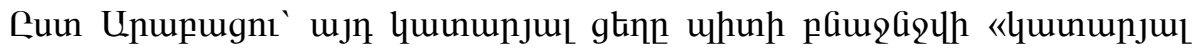

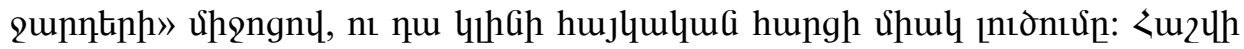

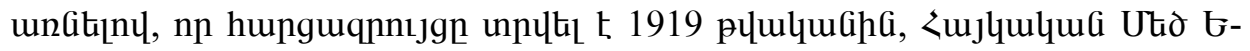

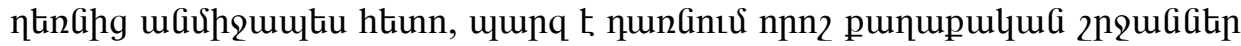

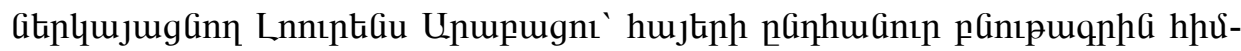

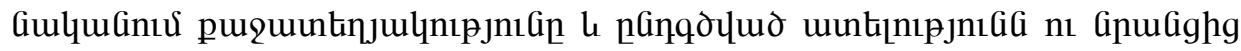

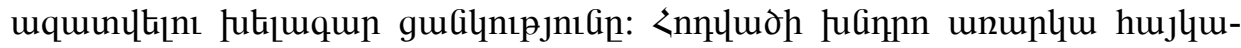

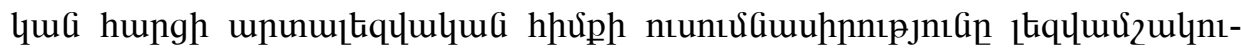

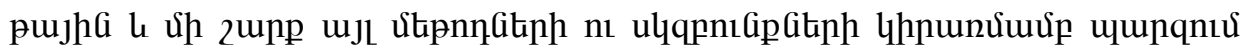




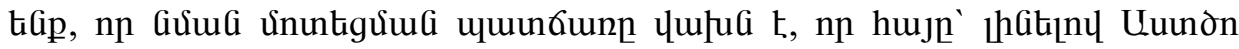

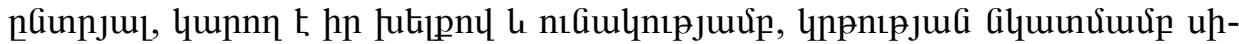

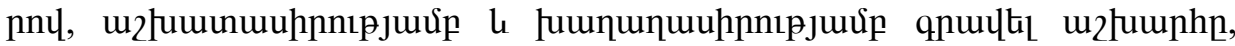

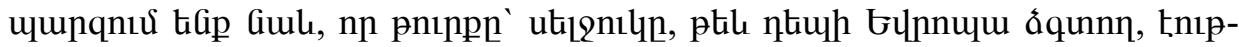

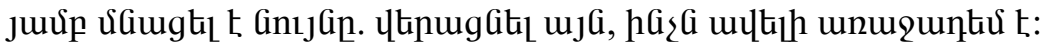

